\title{
Cardiac tamponade in an infant during contrast infusion through central venous catheter for chest computed tomography*
}

Tamponamento cardíaco durante infusão de contraste em acesso venoso central para realização de tomografia computadorizada de tórax em lactente

\section{Danilo Felix Daud ${ }^{1}$, Marcos Menezes Freitas de Campos $^{1}$, Luciano Augusto de Pádua Fleury Neto ${ }^{2}$}

\begin{abstract}
Complications from central venous catheterization include infectious conditions, pneumothorax, hemothorax and venous thrombosis. Pericardial effusion with cardiac tamponade hardly occurs, and in infants is generally caused by umbilical catheterization. The authors describe the case of cardiac tamponade occurred in an infant during chest computed tomography with contrast infusion through a central venous catheter inserted into the right internal jugular vein.

Keywords: Cardiac tamponade; Radiology; Thoracic surgery.
\end{abstract}

Resumo Complicações decorrentes do cateterismo venoso central são infecciosas, pneumotórax, hemotórax e trombose venosa. O derrame pericárdico com tamponamento cardíaco é mais difícil de acontecer e, quando ocorre em lactentes, é geralmente ocasionado por cateterismo umbilical. Descrevemos um caso de tamponamento cardíaco ocorrido durante tomografia computadorizada de tórax, com infusão de contraste por acesso venoso central em veia jugular interna direita. Unitermos: Tamponamento cardíaco; Radiologia; Cirurgia torácica.

Daud DF, Campos MMF, Fleury Neto LAP. Cardiac tamponade in an infant during contrast infusion through central venous catheter for chest computed tomography. Radiol Bras. 2013 Nov/Dez;46(6):385-386.

\section{INTRODUCTION}

Generally, the discussions about complications from central venous catheterization in children concentrate on infectious complications and on the most common mechanical complications such as pneumothorax, hemothorax and venous thrombosis ${ }^{(1)}$.

Nonetheless, pericardial effusion has already been reported by international studies, most of them describing cases of neonates submitted to umbilical catheterization $^{(2,3)}$ and or catheterization through other central venous lines ${ }^{(\mathbf{4 , 5})}$.

\section{CASE REPORT}

The authors report the case of a threemonth-old, preterm child admitted to infant Brazil.

* Study developed at Hospital Geral de Palmas, Palmas, TO

1. MDs, Thoracic Surgeons, Hospital Geral de Palmas, Palmas, TO, Brazil. Brazil.

2. MD, Radiologist, Hospital Geral de Palmas, Palmas, TO,

Mailing Address: Dr. Danilo Felix Daud. 603 Sul, Alameda 14, Lote 19, Plano Diretor Sul. Palmas, TO, Brazil, 77016-374. E-mail: danilodaud@uol.com.br.

Received November 4, 2012. Accepted after revision April 19, 2013. intensive care unit, with acute renal failure and sepsis with a probable pulmonary focus. Central venous access was not available and was obtained by the intensivist physician by means of puncture of the right internal jugular vein. Subsequently, the patient was referred to undergo contrast enhanced chest computed tomography. Immediately after iodinated contrast agent infusion (Figure 1), the child presented clinical worsening and was promptly taken back to the intensive care unit. The thoracic surgery team was called.

Figure 1. Contrast enhanced chest computed tomography images. A: Axial section - presence of contrast in the pericardial sac (effusion) and bilateral pneumonia. B: Coronal reconstruction - presence of contrast in the pericardial sac (effusion).

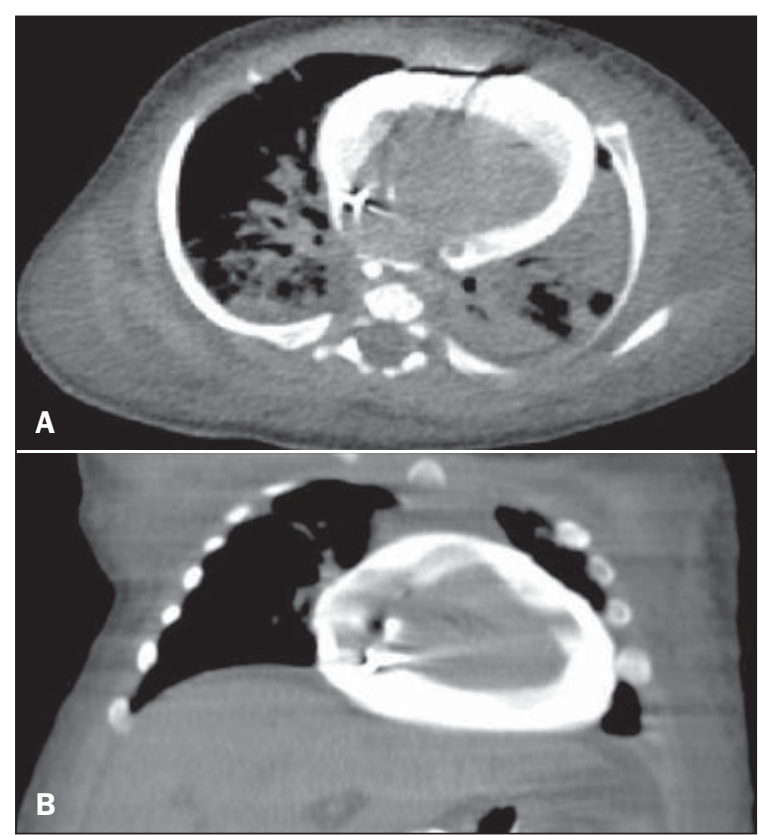


Considering the clinical signs of pericardial effusion with cardiac tamponade and consequential cardiac arrest, pericardiocentesis was performed (Marfan puncture) with aspiration of $30 \mathrm{ml}$ hematic fluid and cardiorespiratory resuscitation maneuvers with heart beat recovery.

The patient was taken to the surgical center assisted by one of the thoracic surgery team members while another member was already prepared to initiate the thoracotomy. Right lateral thoracotomy was performed once the hypothesis of right atrial perforation by the central venous catheter was raised. The surgical strategy included pericardiotomy and atrial cardiorrhaphy.

The child's clinical condition worsened, progressing to death seven days after the procedure due to multiple organs failure.

\section{DISCUSSION}

Pericardial effusion with cardiac tamponade by itself represents a severe problem for any patient. In a frail child admitted to an intensive care unit with other diseases, such a condition is potentially fatal. It may be caused by umbilical catheterization, particularly in neonates ${ }^{(2,3)}$, or other central venous access lines ${ }^{(\mathbf{4 , 5})}$.

The cause and prompt diagnosis of such an event during contrast enhanced chest computed tomography scan make this case rare. No similar case report has been found in the literature.

The authors conclude that careful insertion techniques as well as continuous observation of the correct positioning and function of central venous catheters, be- sides the utilization of good quality materials, are essential to aid in the prevention of severe complications.

\section{REFERENCES}

1. Askegard-Giesmann JR, Caniano DA, Kenney BD Rare but serious complications of central line in sertion. Semin Pediatr Surg. 2009;18:73-83.

2. Megha M, Jain N, Pillai R. Pericardial tamponade in a newborn following umbilical catheter insertion. Indian Pediatr. 2011;48:404-5.

3. Traen M, Schepens E, Laroche S, et al. Cardiac tamponade and pericardial effusion due to venous umbilical catheterization. Acta Paediatr. 2005;94: 626-8.

4. Nowlen TT, Rosenthal GL, Johnson GL, et al. Pericardial effusion and tamponade in infants with central catheters. Pediatrics. 2002;110(1 Pt 1):137-42.

5. Ohki Y, Yoshizawa Y, Watanabe M, et al. Complications of percutaneously inserted central venous catheters in Japanese neonates. Pediatr Int. 2008; 50:636-9. 